\title{
10 In reaction to revolution
}

\author{
Anti-strike mentalities and practices \\ in the Russian radical right, 1905-14
}

\author{
George Gilbert
}

\section{Introduction}

In thinking about the nature of the Russian right's political activism, a dramatic passage from the Union of Russian People's (URP) 1905 manifesto provides the following insight:

The enemies of the Tsar and of the country, by means of deception, threats, and violence, cause strikes in factories and mills, stop trains, disrupt trade, inflict tremendous loss to the entire state, and deprive hundreds of thousands of poor people of work in order to force them into violence through hunger. ${ }^{2}$

In a few short lines, the manifesto demonstrates the populism of the URP, placing this group on the side of the Russian people against subversive enemies, and, at the same time, stating their desire to defend Russian autocracy. It presents the URP as a force for law and order in a time of chaos and unrest, and focuses on the negative energies unleashed by the strike wave in late Imperial Russia.

This chapter will investigate the ideas, mentalities and activities of Russian rightists concerning the strike movement in late Imperial Russia. It will look mainly at parties and unions that styled themselves as social movements. These have sometimes been known (and referred to themselves as) "Black Hundreds", though here the term rightists (or "right") will be used to denote clear reference to the operations of specific actors - those of the right-wing parties (pravye partii). The argument is that the right was a novel force that posed dilemmas not only for their opponents on the left, but also for tsarism. Rightists had an opportunity to share power with authorities, including the army and police, that was never fully grasped. Though partially because of the right's lack of organisational wherewithal and tendencies towards infighting, the more intractable reason why counter-revolutionary activism did not make further inroads is the challenge to autocracy that rightists themselves posed. To illustrate this claim, the essay explores several cases from the 1905 revolution up until the First World War, particularly focusing on examples drawn from Odessa, St. Petersburg and Ekaterinoslav, though it will contextualise such findings more broadly.

The historiography on the strike movement in the late Russian Empire is deeply developed; strikes proliferated in the late Russian Empire from the 1890s in step 
with increasing patterns of urbanisation, industrialisation and the development of the workers' question. ${ }^{3}$ The revolutionary epoch of 1904-7 saw a great upsurge in the strike movement, embodied in developments such as the General Strike of October 1905, which provided a defined problem for Russia's conservatives to contend with. The year forms the point of departure in Peter Holquist's summary of the "epoch of violence" (1905-21) which spanned late Imperial Russia and the early Soviet Union. Violent hostility to strike movements was one part of a much wider pattern of state, non-state and anti-state conflict. ${ }^{4}$ As has been well demonstrated, strikes in late Imperial Russia were often brutally suppressed by the defenders of the old regime, with anti-strike violence deployed by police, Cossacks and the army. ${ }^{5}$ Right-wing forces opposed to strikes were just another example of the old regime's defenders, prepared to use violence if necessary; intriguingly, they were not created by the old regime, but nevertheless rose to protect it.

Historians have rarely lingered long on where the Russian radical right stood in relation to these wider patterns of anti-strike violence and activism, which is surprising given the literature on the Russian right has expanded greatly since the collapse of the Soviet Union. The intellectual elements of right-wing activism their "ideology" - has taken precedence in most studies, alongside study of party and group formation. ${ }^{6}$ Though the "organized right" appeared earlier, the revolution of 1905 and in particular the promulgation of the 17 October Manifesto of that year provided the impetus for a wider process of right-wing group formation. The appearance of politics, parliament and civil rights compelled the appearance of new forces on the right that wished to restore Russia to an earlier time, before developments they negatively associated with both Russian and non-Russian liberalism. The final few months of 1905 saw the formation of many significant forces on the right, such as the URP, whose manifesto has been already cited, though they were joined by many smaller and less notorious organisations.

The Russian right, it must be said, was a diverse and differentiated series of organisations, and the boundaries between different groups and parties were often remarkably porous. Activists and leaders often crossed the boundaries from one group to another before, during and after the revolution of 1905, helped by the close ideological connections between the main parties and groups, and the tendency for key individuals to be closely networked to one another. Many figures appear on the membership lists of several different groups, and it was not uncommon for those previously active in groups like the Russian Assembly to later on play a role in groups including the URP or the Union of the Archangel Mikhail, which was formed at the start of 1908. However, the names of these groups - for instance, the Party of Legal Order - illustrate a commonality: a desire to defend the existing state structure. Rightists were deeply troubled by what they saw as the disorder and chaos of the new "time of troubles" that started around 1904-5, and shared a pessimistic, even fatalistic vision of the Russian future. ${ }^{7}$ A theme uniting disparate groups on the right was their opposition to revolutionary activity, including strikes and striking workers.

Exploring the right's anti-strike activism provides vital clues to uncover their relationship with the existing forces of law and order. Hans Rogger has shown 
that the Russian right was largely created autonomously from the government and supported by influential backers, some of whom could not be dismissed as lackeys of the tsarist establishment, as Soviet-era scholarship on the right tended to do. ${ }^{8}$ They tended to emerge at their own behest and their actions were not organised by employers' associations. Furthermore, rightist desires to oppose strikers and tendencies towards violence complicate their self-image as loyal defenders of law and order, and can shed light on an important question: to what extent were such groups - particularly armed groups - accepted by the Russian state when they themselves created disorder? In summarising the pan-European impact of armed associations at a colloquium on the theme, Heinz-Gerhard Haupt noted the importance of specific "conflict structures" in accounting for the emergence of violence, and, influenced by Max Weber's reading, the problem of legitimate violence in particular. These structures included the relationship between insurgent forces and existing authorities such as the army and police, and the latter's monitoring, and, if necessary, suppression, of the potential for violence. ${ }^{9}$

Right-wing efforts to organise parties and groups at the local level were often piecemeal and haphazard, but their appearance posed intriguing dilemmas for the Russian state. ${ }^{10}$ Haupt's concluding questions are appropriate: how does a state, in this case an autocratic one, deal with violence deployed outside of its public monopoly on it? To what extent were such groups integrated into the state's monopoly on violence? Counter-revolutionary violence was not new: it was seen in the pogrom wave from 1903-5. Focusing on anti-strike activism as extraauthority practice illustrates a changing, often vexed relationship between the Russian state and autonomous forces. This chapter will contribute to our knowledge of both the Russian right and political violence in the Belle Époque era by exploring the nature of this relationship, examining the shop floor culture of the right as well as their ideas, visions and practices towards strikes, revealing diverse sides of the new activist mentality, one often developing outside of the auspices of the autocracy.

\section{The workers' question and right-wing mobilisation}

The Russian right's hostility to strikes was partly a question of identity, linked to the wider development of such groups, as well as the desire to articulate and clarify a response to the "workers' question" in the late Russian Empire. This was underscored by structural transformations in the Russian Empire, most of all urbanisation and industrialisation, especially from the 1880s onwards. Thinkers on the conservative right, including the ultra-monarchist Lev Tikhomirov (formerly, a member of the revolutionary group the People's Will in the early 1880s), began to explore such issues in their writings. The Russian Assembly, a cultural organisation formed in St. Petersburg and Khar'kov, first appeared in $1901 .{ }^{11}$ The Assembly and its leaders - who originated exclusively from the gentry estate initially had little to say about working-class activism, and their supporters came almost wholly from the elites, mainly the Russian nobility. In contrast, a few years later new groups attempted to appeal to a broader base of social support, 
including from workers. The names of new groups are suggestive of this trend: the Union of Russian Workers (Kiev) and the Circles of Russian Workers (Khar'kov) were two that appeared during 1904. ${ }^{12}$ This marked a transition whereby new parties and groups were clearly aiming to cultivate the support of workers by addressing them directly. At this stage such organisations had little to say about strikebreaking as a practice, and their calls to support the Russian autocracy did little to distinguish them from older conservative groups. Over time though the nature of their appeal began to change; publications and pamphlets began to address workers specifically, as in the case of a pamphlet addressed "to Russian workers" issued in Kiev in April 1905. ${ }^{13}$ The "workers' question" began to preoccupy intellectuals on the right as well: early in 1905, Klavdii Paskhalov, a noted Slavophile thinker who was also active in right-wing circles after 1905, spoke of a possible "revolution from the right" as one response to challenges of mass activism and political radicalism. ${ }^{14}$

During the revolutionary events of that year a larger strike movement appeared, culminating in the General Strike of October 1905, a major event that urged many of the newly formed parties and groups on the right to clarify a response. The response of many was to organise, and, around the same time, many parties and groups on the right desired to attract workers to their cause. From late 1905 the right expanded massively across the empire, and the formation of their own workers' groups followed patterns of national party formation. Groups like the URP exemplified a more intransigent, radical presence developing on the right in this era, some of which styled themselves as social movements (or "unions") rather than political parties, telling of the diverse constituency they wished to attract. Even so, the URP, by far the largest and most socially variegated of right-wing groups, still drew 50 per cent of its ruling council from the gentry even after the revolution of $1905 .^{15}$

And yet evidence shows the URP sought to recruit factory workers from the final months of 1905, some of whom were attracted by their specifically antirevolutionary message. A group in the Putilov factory in St. Petersburg, one of the largest manufacturing plants in the Russian Empire, which boasted a total workforce of around 30,000, was led by Aleksandr Polovnev; another group in the city was in the Nevskii factory, headed by Vasili Snessarev. The URP's presence in the Putilov factory towards the end of 1905 was estimated to number around 1,500 workers. ${ }^{16}$ The formation of a so-called "fighting brotherhood" (druzhina) amongst URP activists in nearby St. Petersburg demonstrated a potential for conflict. Developing a base of supporters amongst factory workers was linked to opposition to striking workers, depicted as ruinous social and political forces in an atmosphere of febrile crisis. ${ }^{17}$ The names of some of these new groups provide clues to their intention: one was called the "Society for an Active Fight with Revolution". Police records during 1907-8 estimate that together there were 3,5004,000 "Black Hundred workers" (chernosotenets-rabochii) in the St. Petersburg area when taking into account the participation of all sympathetic organisations. ${ }^{18}$

Some of the most concentrated areas of right-wing activity were in newly industrialised regions to the South and West of the empire, in Ukraine. These contained 


\section{George Gilbert}

large manufacturing plants, an active revolutionary movement and a variety of social, political and ethnic tensions that gave ample forces for right-wing movements to react against. The presence of many of these groups is recorded by the reports of the interior ministry (police), which includes lists of membership figures of rightist workers' organisations such as the Union of Russian Workers (URW). For example, the Ekaterinoslav branch in the Briansk factory, along with activists from the Trubnoi and Shoduar factories, were together estimated to comprise possibly more than 1,500 people. The URW branch at the Zaporozh'e Kamenskii factory in Ekaterinoslav district had an even larger membership, potentially consisting of 3,000. The section at the Auerbakh factory in Bakhmutskii district, also in the Ekaterinoslav region, perhaps included around 300 people. These reports, all dated from 13 September 1907, suggest a total presence in the Ekaterinoslav area of around 4,800 activists. These reports do not present the total number of workers employed at the factories, so gauging their overall success in recruitment is impossible, but these do represent sizeable figures, especially when placed in comparative context with rightist groups elsewhere. ${ }^{19} \mathrm{Kiev}$ also contained active branches of the URW, estimated to be around 3,000 strong in 1905, and, according to the vice-governor of Kiev, closer to 6,500 towards the end of December 1907. ${ }^{20}$ One could expand on this image with reference to a far greater number of towns and cities, but the general trend is clear: recruitment gathered pace from the end of 1905, continuing into 1906-7.

In addition to increasing numbers, rightists also sought to recruit different types of workers. As well as targeting skilled plant workers in large factories like the ones at Putilov and Nevskii in St. Petersburg, appeals were aimed at low-skilled and seasonal workers, including in areas of pronounced mobility and transition. The latter can be seen in the port city of Odessa, another prominent area of rightwing mobilisation. Efforts to mobilise focused on the recruitment of loader workers in the port area, which had been a hotbed of revolutionary radicalism during the preceding years, but several hundred workers were recruited to the right in Odessa during 1906-7.21 Generally speaking, right-wing support came more from temporary and seasonal workers, as well as low-skilled labourers (chernorabochii), especially in Odessa and other regions to the South West where industry relied on seasonal workers for much of the work, such as in Odessa's docks. Indeed according to one police report from the region in July 1907, the term chernorabochii had become synonymous with members of the URP. ${ }^{22}$ The result can be seen in the formation of artels (workers' cooperatives) amongst workers from the end of 1905 in the region, which included many of these lower-skilled seasonal labourers.

A corpus of printed texts, including manifestos, books and pamphlets, make the right's sustained effort to tailor materials to a working-class demographic abundantly clear. Many pamphlets were directed "to workers", "to working people" or alternatively to "the masses": nine of the 20 texts published by the Khar'kov branch of the URP listed in the March 1907 issue of the journal Mirnyi trud (Peaceful Work) had variations of these words in their titles..$^{23}$ The messages of such pamphlets typified the central ideological tenets of right-wing groups that 
had cohered into the recognisable tsarist formula of "faith, tsar and fatherland" over the past several years: indicative of the continuing commitment to a strong, centralised state, Russian Orthodox religion and Russian national identity. ${ }^{24}$ The core ideas of the right, then, did not represent an obvious challenge to the existing order, so much so that they received some government funding, especially for their newspapers and journals. Petr Stolypin's assistant at the Ministry of the Interior S. E. Kryzhanovskii reported in his memoirs that rightists received substantial disbursements from his office for their press; the newspapers Russkoe znamia (Russian Banner) was allocated 30,000 roubles and Zemshchina (Realm) was allocated more than 10,000 roubles a month. ${ }^{25}$

Even so, there was a clear challenge presented by the management of a larger, voluble and - at times - more vehement right-wing presence. The state's task of managing these new parties and groups in an under-governed empire with often low densities of police and army was not an easy one. ${ }^{26}$ Some of the right's new clusters focused on martial action, such as the "fighting brotherhoods" (druzhiny) of the URP. This connected to older traditions of nationalist violence such as the pogroms, and the ethnic violence practised by groups known collectively as the "Black Hundreds", labels which the URP and others borrowed to describe themselves on occasion. Much of the right's activity contained within it a more political focus in this period. Such hostility could be directed against national and ethnic enemies - most of all Russia's Jews - but also the revolutionary left, bound up in the new mindset with the current strike wave. Such identities often intersected in the minds of the activists joining the groups, as well as their leaders. What follows is an investigation into the political culture surrounding rightist hostility to the strike wave.

\section{Anti-strike mentalities and activism}

A marked feature of the right as it appeared during and after 1905, including many of the groups listed earlier, was the desire to oppose and resist strikes. This was in part a reaction to the revolutionary events of 1905 itself and a wider strike movement. We can see from the declarations of the central councils a recurrent depiction of strikes themselves as ruinous and destructive formations that needed to be opposed. ${ }^{27}$ The newspaper Moskovskie vedomosti (Moscow News) was edited by Vladimir Gringmut, a noble of Slavophile conviction who had set up the Russian Monarchist Party (RMP) in April 1905. The paper carried an editorial opposing strikes for economic motives: as a party, their policies sought to develop and preserve Russian industry, and they made the obvious point that the strike wave would cause major economic harm. ${ }^{28}$ In the regions too, such ideas can be clearly seen. The Tsarist Society of the Russian People appeared in the city of Kazan at the end of 1905 and included in its literature a desire to oppose strikes for "economic" reasons, as detailed in a circular passed around the Alafuzovskii factory. ${ }^{29}$ Similar ideas circulated in the congresses of the major right-wing associations, like in the Fourth All-Russian Union of the United Russian People, which met in Moscow during 1907. ${ }^{30}$ 


\section{George Gilbert}

An intriguing feature of rightist activity was its shop floor activism, with a number of rightists justifying their actions in economic terms, a natural corollary to their protectionist and autarkic policies. ${ }^{31}$ Following the 1905 revolution, a range of powerful employers' associations formed, such the St. Petersburg and Moscow Societies of Factory Owners (1907). Evidence suggests rightists continued to mobilise independently, away from large employers' associations, who probably viewed their activities with suspicion. On occasion, right-wing organisations showed a clear desire to work with Russia's major ministries. In May 1907 a liberal journal reported on the murder of two railway road foreman, Ivanov and Mylov, who were responsible for overseeing operations in the Aleksandrovskii factory in Ekaterinoslav. In response, workers had been on strike in the factory, leading to its closure. In response to the closure, the main council of the URP claimed that it wished to enter into an agreement with both the Ministries of Internal Affairs and of Work and Industry to keep the factory going, showing a desire to work closely with the Russian authorities. They claimed many workers would go without food as a result of the strike, so it was vital for people to continue to work. The URP branch stated that the vast majority of workers had been led astray by a small but well-organised clique of revolutionaries and that the economic consequences of the shutdown would make ordinary Russian workers suffer. ${ }^{32}$ Elsewhere, a petition addressed to the minister of internal affairs from the aforementioned Tsarist Society of the Russian People claimed that the closure of the Alafuzovskii plant as a result of the strikes in late 1905 would mean the loss of bread for "several thousand people, including women and children". Another feature of the same report makes the populist intentions of the right clear by attacking the factory owners who "had received enormous profits" in the preceding years. ${ }^{33}$ Though these groups wanted to open connections with the authorities in resisting strikes, the formation as well as populist instincts of these new parties and groups represented a potential threat to order on the factory floor.

Some branches went beyond articulating a justification for resistance to strikes and disorders into a much wider tranche of activities. A branch of the Union of Russian Workers active in the Briansk factory, Ekaterinoslav, which saw itself as a working-class organisation for "truly Russian" people, claimed that its main aim was to stop the unrest seen during the revolutionary year. The reasons to resist strikes mirror those previously outlined, and the union also declared its desire to work with factory owners and foremen to stop the harmful spread of strikes and oppose revolutionary forces. No armed resistance to strikes during this period is described: violence was considered the preserve of both the Social Democrats and Socialist Revolutionaries who had been active in the factories over the preceding years. In contrast, the union was described as a peaceful group which had provided food and support to the families of poor and unemployed workers at Easter time. Its activities were described as charitable, cultural and educational, with activists involved in establishing libraries and reading rooms to educate the families of workers. This was part of a desire to show the right as on the side of the Russian people, bound up with endeavours that suggested care. In this, the desire to resist 
strikes, painted in wholly negative terms and associated with the political left, is also clearly expressed. This political culture was developing independently of any promotion by the state, led and guided by the leaders and activists of right-wing groups themselves. ${ }^{34}$

This populist vision was infused with a streak of anti-capitalism, hence the derogatory reference to factory owners in Kazan: economic growth in itself was not held to be a good thing. Though the right frequently described themselves as "apolitical" or alternatively "above politics" - two frequent tropes on the Russian right (and, indeed, the right elsewhere) in this period - what we instead see as a major motivation is pronounced hostility to the political left. In almost every instance scrutinised, an active left was necessary for a right-wing group to form: putting it in other terms, the "revolution" necessarily preceded the "counterrevolution". In the Briansk factory, the Union of Workers had appeared first out of a desire to stop the revolutionary left by a group of "patriotic" local workers. ${ }^{35}$ In the Semiannovskii factory in St. Petersburg, a group called Tver' promoted an idea of resisting the left including the Social Democratic movement, if necessary by a "fight". The group was set up by leaders I. Lavrov and V. Snesarev to combat "red terror" in the factories and leant on both factory bosses and foremen for support. ${ }^{36}$ Elsewhere in St. Petersburg, workers at Putilov mobilised out of a desire to oppose revolutionary left activity in the factory; they were in receipt of a batch of revolvers from a local organiser of the URP, Iuskevich-Kraskovskii, which were likely passed on to him from the civil authorities. ${ }^{37}$

A view that the 1905 revolution was not Russian often appeared in the declarations of workers' groups on the right, including those that sought to oppose strikes. Most of all this hostility was directed against Russia's Jewish citizens, highlighting the prevalence of antisemitism, but also towards a range of national and religious minorities. The April 1905 edition of the right-wing journal Mirnyi trud reported on the formation of "Workers' Patriotic Circles" in Odessa under the leadership of N.N. Rodzevich (who would later become active in the Odessa branch of the URP), and their desire to oppose their stated enemies in the region, namely radicals, socialists and Jews. ${ }^{38}$ For Konovnitsyn, later leader of the URP in Odessa, a major stimulus to the group's formation was to oppose revolutionary and, in particular, Jewish workers, with the revolution itself conceived of in national and religious terms. ${ }^{39}$ An article by an unknown author in Moskovskie vedomosti from February 1906 on "Workers and Revolution" listed a number of new organisations on the right that appeared in Tula, Iaroslavl and Ekaterinburg, expounding on how workers had been influenced by European and/or Jewish ideas which had encouraged them to strike. ${ }^{40}$ Similarly, a 1906 pamphlet written by Ivan Sobolev titled Zabastovki (Strikes) provided a historical overview of the strike movement in Russia and the West, claiming Russian workers were opposed to strikes but had been manipulated by Poles and Jews. ${ }^{41}$ Union leaders themselves were presented as exploitative: "You will get officials of a certain 'union' on the lookout for a simple man, waiting for a convenient time, and then taking his 'union' money". ${ }^{42}$ Such appeals created a conspiratorial worldview, mixing images of harmful revolutionary politics, mendacious unions and the subversive 
influence of non-Russian groups, suggesting manifold threats to the core ethnos of Russian people in the empire.

\section{Conflict and violence}

The end result of this hostility could be conflict in different regions of the Russian Empire, including in its largest cities. ${ }^{43}$ Laura Engelstein's work on conflict in Moscow explored the appearance of violent "patriotic" demonstrators appearing in response to socialist and liberal forces that had mobilised in November and December 1905. The governor-general of Moscow V. Dubasov sought to quash the large-scale insurgency of Social Democrats and other radicals by drawing on these emergent forces, organising volunteer militias with the support of a new range of groups, including the then recently established URP. These counterrevolutionary movements were active under the direction of the police. ${ }^{44}$ Following the violent crushing of the Presnia uprising in the city centre in December 1905 by the police and army, the URP branch in Moscow declared itself to be an anti-strike force; in the rightist newspaper Veche (Evening) it was described as a society for an "active fight against revolution", which aimed towards the "destruction of rioters" (istrebliat' kramol'nikov). ${ }^{45}$

A particularly vehement URP presence was recorded in Odessa, where rightists portrayed themselves as strong resisters of leftist anti-state disorders. The interim governor-general of Odessa at the outset of 1907 P.F. Glagolev looked on them sympathetically, considering them a useful counterweight to revolutionary forces: "they have already realized the harm that comes from unrest, robberies, theft and strikes, and therefore fight against them" ${ }^{46}$ In addition to the presence of rightists amongst dockworkers, we should note the registration of a workers' artel with links to the right in Odessa. ${ }^{47}$ Count A.I. Konovnitsyn, who had previously been involved in the Russian Society of Shipping and Trade before becoming the head of the Odessa URP in the city, was responsible for organising an artel amongst port workers in the city. The groups under his direction were raised at a time when the radical left was mobilising and aimed to physically confront radicals and get Russia's docks working again after the disruption from strike activity seen following the October 1905 General Strike. ${ }^{48}$

Police surveillance reports describe the actions of the URP in the area, led by Konovnitsyn, V.I. Pelikan and A. Kakhov during 1906 and 1907. Though intriguing, the sources can be suggestive and at times lack texture. Sometimes, it is not clear from the reports what is exactly going on, as they note clashes and collisions without going into much depth about the nature of these. However, in other instances we can more clearly discern what is occurring: looking closely at police records and newspaper reports of the era together can give us an effective outline, including of instances of violence in the midst of strikes occurring in Odessa through 1906 and 1907. Groups of right-wing activists confronted striking Social Democrats and others from the revolutionary wing of Russian politics, which could result in violent confrontation. Much of this occurred in the dock areas around the port region in the city centre; the ships and unloading bays were the 
scenes of skirmishes between the Odessan right and its enemies, an open area in the city with much footfall that naturally attracted the attention of a variety of actors, including the local police, Social Democrats in the region, and, indeed, Jewish radicals who wished to strike back against the right. ${ }^{49}$ This conflict between revolutionary workers, Jewish self-defence forces and right-workers from artels formed in the region served to increase tensions and disrupt the town's shipping, trade and industry - an ironic twist given how URP leaders couched the actions of the group as defending the Russian economy and state in a time of strikes and disorders. ${ }^{50}$ Elsewhere, URP activists appeared on the campus of Odessa's major university in December 1906 in response to strikes and disorders, apparently provoked by the presence of student strikes. ${ }^{51}$ This is representative of the wider culture of revolutionary violence and counter-violence visible across the city in the era.

The exact scale of the right-wing success in suppressing strikes is open to debate; evidently, the right's own, reflective sources in recording this activity are subjective. Recalling his organisation of the group, Konovnitsyn described the violent breaking of the strike movement and clashes between URP activists and revolutionary workers in 1906, when the URP "thwarted and finally stopped the disastrous strikes amongst steamship workers who loaded and unloaded the ships" in the Odessa docks; he continued that these clashes "brought many benefits to Russian shipping, saving it many millions from strikers" ${ }^{52}$ If he exaggerated the scale of this, other sources corroborate his claim of success: a telegram sympathetic to the URP published in the national newspaper Novoe vremia (New Time) on 28 November 1906 commented upon their activity in Odessa as follows:

not a word has been said about the strike that was broken by the Union of the Russian people ... as far as we know, this is the first time in Russia, that the energy of members of the Union of the Russian People has had a destructive edge over the revolutionary workers [movement $].^{53}$

It is worth considering why the URP could gain a foothold on Odessa and employ such action effectively. At first, the Odessa branch of the URP benefitted from a largely hands-off approach on the part of the authorities, previously seen in the testimony of Glagolev, which aided their attempts to generate violence and discord against the left. The reasons for this were structural as well as cultural: as a recent formation in an under-governed empire with low-density regular policing, they profited from a degree of organisational laxity amongst the Odessa authorities. As self-stated defenders of law, order and Russian industry, they had the advantage of appearing as a counterweight to revolutionary forces that had caused a lot of unrest in the city over the preceding several years. It is also worth considering what type of weapons URP activists had at their disposal to strike fear into their enemies. Reports suggestive of violent "clashes" but with relatively few casualties might lead one to suspect cudgels or even fists as primary weapons, but other types of arms could be distributed amongst supporters to threaten and potentially kill or injure opponents. In one instance in April 1907, 20 revolvers 
were distributed amongst the Odessa URP by the Russian Society of Shipping and Trade - the organisation previously headed by Konovnitsyn - for the protection of this society by members of the URP against revolutionary forces. In a letter to the mayor of Odessa, the head of the society noted the need to do this given violent attacks by revolutionaries on officials from the society in recent times, citing a "night attack on the port by revolutionaries, who bombed, shot and wounded people" and were then expelled from the port area by guards. ${ }^{54}$ Noting the destruction wrought by revolutionaries was a straightforward and emotive way in which radical rightists could justify their actions, both to themselves and the Russian authorities.

However, this form of activism posed challenges to the authorities as well as the right's erstwhile enemies. We can clearly discern a change in the authorities' attitudes towards the URP through 1906 and 1907; in part, this was a question of changing personnel within the military and civil authorities, some who regarded the URP with suspicion, but in other areas, it was a question of the activity and temper of the groups themselves. Whilst the URP and others searched both for authority support and a wider presence, their desire to provide an armed presence against revolutionary agitators made some in authority nervous. In one instance, the acting State Controller D.A. Filosofov declined a request from Konovnitsyn to organise a series of meetings on merchant ships in the Odessa dock region; it was added in the report that Prime Minister Peter Stolypin and all cabinet members present agreed with Filosofov's actions. An article from August 1907, published in the newspaper Tovarishch (Comrade), noted that a number of revolvers and "illegal" literature from the URP activists were confiscated following a recent skirmish between these activists and their revolutionary enemies, no doubt a reference to the recent distribution of weapons to Konovnitsyn under the auspices of the Russian Society of Shipping and Trade. The report did not include a specific reason as to why Konovnitsyn was not allowed to mobilise his forces on Odessa's merchant ships, only insisting such denials came from on high. ${ }^{55}$ Bands of rightwing activists, sometimes described as "unionists" (soiuzniki) in such reports, were occasionally arrested by police: one reason could be that they were in possession of weapons, including revolvers and other types of arms. ${ }^{56}$

Eventually, the tide began to turn against the right in Odessa. Judging from the source record, clashes between the right and the revolutionary left and strikers tailed off after 1906. Partly, this is a result of the dissipation of the 1905 revolution's major energies and the gradual restoration of authority across the Russian Empire. Another, more local reason was the changing stance of the Odessan authorities. We have seen how police began to monitor rightists more closely and, if necessary, suppress them, but Konovnitsyn also lamented a lack of financial support from the authorities that he had sought to co-opt since 1906. In his efforts to stop what he saw as his Jewish enemies, he noted the presence of "unfriendly clerks" within the state bureaucracy, and he sought the "removal" of such people. 57 This criticism of the bureaucracy was a trademark of the right, which saw them as full of enemies of different types; such a conspiratorial mindset was emblematic of Konovnitsyn's worldview and can partly explain the infighting that later split 
the right in Odessa. This has been identified in Jacob Langer's research, which has shown how the right in Odessa was riven by factionalism, driven in part by financial corruption. Such scandals within the URP drained the groups of muchneeded resources and affected many of their activities in the region, including strikebreaking and armed resistance to the left. ${ }^{58}$

Union activism dropped significantly after Petr Stolypin dissolved the Second State Duma in 1907, a period which signalled the ascendancy of the government's "repression and reform" response to the 1905 revolution. Even so, unlike in some other areas of the empire, the right in Odessa was active up until the eve of the First World War. The resurgence of the strike wave in 1911 provided new opportunities for anti-strike activism. One instance was the press strike of that year: the newspaper Odesskii pechatnik (Odessa Press) cites the use of members of the Odessa URP as strikebreakers by a newspaper owner, one Abraham Finkel, though given his Jewish identity, his desire to call on them as his strikebreakers (and have them obey him) in order to halt the press strike seems implausible. ${ }^{59}$ What is more certain is how limited toleration from the civil authorities affected the development of the right in Odessa. Konovnitsyn appeared to have an uneasy relationship with the governor-general of Odessa I.N. Tol'machev, who, unlike some of his predecessors in that office, perceived a large and voluble right-wing force as a threat. Initially Tol'machev appeared supportive towards the URP, but in later years Konovnitsyn wrote in his personal communications about Tol'machev's "frequent clashes" with both himself and the URP. In one letter, Konovnitsyn reflected on Tol'machev's role in suppressing the strike movement on 1911 in Odessa, claiming that Tol'machev deliberately allowed the strike movement to gain purchase before suppressing it himself, so that he could proclaim himself as a "saviour and suppressor of riots and unrest" in Odessa rather than credit Konovnitsyn and his followers, in order to convince those in higher office of his own moral probity. ${ }^{60}$ Suspicion of the URP increased the further the 1905 revolution receded into the distance, exacerbated by the low density of regular police across much of the Russian Empire. It is important to note rightist activism continued for longer after this point, as demonstrated by occasional resistance to the strike wave.

The regional perspective to much of this activity could be considered, as many right-wing groups proved most enduring in the South and West of the empire. This was especially the case near or within the Pale of Settlement, which contained a large Jewish population and had a history of revolutionary activism with many of these forces proudly self-identifying as Jewish. The most famous of these was the General Jewish Workers' Union (Bund), a Social Democratic mass movement that championed universalism. This gave rightists presences to mobilise against. Kiev had been a prominent site of right-wing mobilisation from late 1905, and in a telegram from February 1912 (a year before the notorious Mendel Beilis trial of 1913 when accusations of Jewish ritual murder swept the region and beyond), the governor of the region A. F. Girs noted the presence of groups that positioned themselves "for law and order" against strikers. Whilst the source record is not always clear exactly on who these people were, most telling is the claim that these "patriotic" manifestations could count on authority support if they felt it was desired. ${ }^{61}$ 
Sources from other parts of the Russian Empire show a fragmented and disunited right, or one that was in the minority in the political and social struggles taking place in Russia's factories. In Iaroslavl' during October 1906, strikebreakers appeared after rightists led by the monk Aleksei had distributed sympathetic newspapers such as Pochaevskii izvestiia (The Pochaev News) and Russkii narod (Russian People) in the factories. ${ }^{62}$ Other reports from the time suggest that propaganda was distributed on the part of the URP and others, but sympathisers were in the minority, with most workers in one of Iaroslavl's major factories demanding the removal of agitators who were in favour to the right. ${ }^{63}$ Rightists were involved in physical fights on the factory floor with members of revolutionary organisations but were often on the losing end of such collisions. The main reason for this is that their revolutionary enemies often outnumbered them in clashes, even in areas with a pronounced right-wing presence like Iaroslavl. Workers sympathetic to the right could be the target of hostility from others who sought to drive them out of the factories. ${ }^{64}$ One worker, Volodin, employed at the Wolf metallurgical plant in November 1906, was said to have outraged fellow workers with declarations sympathetic to the extreme right (described as "black hundreds" in the newspaper report), and workers demanded his dismissal by the administration, or else they would kill him themselves. ${ }^{65}$ Though vocal, the likes of Volodin were in a clear minority in this factory, and under threat from workers who did not share their views.

Though they sought to court the authorities with promises to resist strikes and disorder, even in areas where the right had a more effective presence evidence shows that right-wing strikebreakers could attract the suspicion, if not outright hostility, of the forces of law and order. Whilst their message to free Russia from the shackles of strikers was consistent, the mixed response they received from local populations and the authorities placed rightists in a contradictory position. On the one hand, they claimed to be shoring up Russian autocracy in a time of chaos, but on the other they demonstrated a contribution to instances of localised and sporadic conflict that required extra policing. Intriguingly, what these sources together do not show is factory owners and major industrialists themselves supporting right-wing strikebreakers - at most, we have rumours of isolated instances that have dubious accuracy, such as that of Finkel. This supports the claim that rightists in this era were acting mostly at their own behest, separate from the machinations of big business as well as from the authorities.

\section{Conclusion}

To return to the dilemma outlined at the start of this essay, 1904-7 was a period of turmoil in the Russian Empire, with strikes and disorders stretching authorities to their limits and beyond. Rightist strikebreakers saw themselves as defenders of law and order, but, even so, the realities of their activism posed problems for the authorities. They claimed to be defending both Russian autocracy and a strong state power, as well as to be resisting revolutionaries. These were instincts shared by many within the state's structures, but the right's independent development 
led to a continuing ambivalence about how to perceive and respond to them from the Russian authorities. Most of all, violence practised outside of the tsarist state's public monopoly on it raised a question of whether such groups could be integrated within the boundaries of legitimate conflict. ${ }^{66}$ Rightists' radical temperament, desires to resist other armed forces and tendencies for violence all posed challenges at a time when restoring law and order was most crucial. Sources provide intriguing glimpses into an emerging shop floor culture surrounding rightists operating in factory environments, and their wider activism in areas of conflict. That all of this was developing away from the state - increasingly so from around 1906 after the State Duma's appearance - was what led to suspicion, with armed supporters of autocracy representing both a tribute and a threat to the Russian state.

To break down this larger historical question one can consider wider points about social structure as well as the role of key individuals. In Odessa, rightists gained traction because of the presence of specific actors active in shaping and guiding the right (such as Konovnitsyn), and a passive if not outright supportive establishment, exemplified by governor-general Glagolev late in 1905 and early in 1906. Additionally, the demographic structure of the city, with its history of worker-activism, organisation and, more recently, violent resistance to authority provided forces to react against. The interplay between these personal and structural factors allowed the right in Odessa to gain a foothold. To draw a parallel with the pogrom wave that appeared in Odessa a little before the wider formation of the political right there, commonalities existed in terms of structural factors. Gerald Surh's research on Odessa and Ekaterinoslav during the 1905 pogroms demonstrates how the police and army dealt with localised patterns of anti-Jewish violence, and the structural conditioning that allowed the pogrom wave to gain purchase in the first place. In both cases, urbanisation, hostilities between Jews and non-Jews and tolerance of so-called patriotic demonstrators by civil and military authorities can help to explain the appearance of the pogrom phenomena in these two cities in Ukraine. ${ }^{67}$ It also highlights that there was a legacy in terms of counter-revolutionary violence being practised outside of the state's ability to control and manage it, seen here in the wide prevalence of pogroms in 1905. In cases in which rightists provided a possible counterweight to revolutionary forces they received greater latitude from the authorities, but such a stance had the capacity to shift, as seen from the gradual hardening of approaches towards the right in Odessa from 1906 to 1907. On the other hand, rightists also had the problem of attempting to implement a message directed at "truly Russian" people in areas of the empire with high densities of non-Russians, counting on high levels of animus in the Russian sections of the population towards national and ethnic minorities to successfully spread their ideas. This was not always the case in an empire that was remarkably diverse in its social, national, ethnic and religious make-up.

Still considering structural impediments, the right's influence amongst workers and strikers brings to mind the formation of "patriotic" unions under the guidance of police chief Sergei Zubatov from 1902 to 1903. This period, known as the Zubatovshchina (time of Zubatov), was an experiment by the secret police 
to infiltrate and collaborate with the trade union movement to try and encourage working-class loyalty to the state and stop strike action. Though wary of copying his techniques too closely - and often lacking the organisational wherewithal to enforce complex strategies of infiltration and collaboration - some rightists considered that there were lessons to be learnt from this movement and sought to apply them following the 1905 revolution. ${ }^{68}$ However, the Zubatov experiment eventually failed to achieve the authorities' aims: not only did it fail to split the Trade Union movement, it provided many workers with (often formative) experiences of a distinctively unionised identity, as well as practical experience of how to oppose government practices. ${ }^{69}$ Therefore, the recent heritage of patriotic forces operating in close proximity to union culture was not a positive one for Russia's authorities, and this institutional memory clearly affected their practices in the following years.

An important wider point raised by this case concerns development in Russia's legal culture and, connected to this, civic rights and conceptions of political pluralism. The right's antipathy towards strikes was an integral part of its dislike of civil rights. One of the state's responses to striking and revolt had been to grant a series of concessions, culminating in the 17 October Manifesto in 1905. In fact, many rightists saw the constitutional settlement associated with the civil rights enshrined by this manifesto as illegitimate in itself. This was part of a wider view that liberal political reform was a mendacious tool of Russia's enemies located within the subversive structures of politics, parliament and bureaucracy, which had emanated from harmful "Western" (i.e., non-Russian) trends. This illustrates that the right was developing independently of the state and even - to some extent in collision with it. A key point was the appearance of, properly speaking, politics and parliament; some on the right did engage with Russia's Duma - especially the Union of the Archangel Mikhail from 1908 - but this was less the case for groups that considered themselves to be primarily social movements, which have been the focus of this chapter.

The presence of rightists in socially mixed zones of conflict, their hostility to the new legal order and also authorities' lingering suspicions of worker activism all contributed to an ambivalence between sources of state authority and the autonomous right. This presented an important conceptual dilemma in terms of power sharing as outlined by Haupt, but we should also consider local and regional factors that together provide us with a complicated and mixed picture, reflected by the source record analysed herein. Rightists continued to venerate the semi-autocratic monarchy but appeared in an era of politics and parliament that they on the whole deeply opposed: an intractable issue, and one that they never managed to fully resolve.

\section{Notes}

1 I would like to acknowledge the leaders of the PREWArAs project for inviting me to participate in their workshop "Industrial vigilantism, strikebreaking and patterns of anti-labour violence, 1890s-1930s: A comparative and transnational perspective", held by the History Faculty at the University of Oxford in October 2018. In addition the 
resulting essay has been greatly improved by comments from colleagues at my home institution's internal seminar, "Conversations about Research", held at the University of Southampton during February 2020. Particular thanks to Joan Tumblety, Mark Cornwall, Peter Waldron and Christopher Prior for their comments on earlier drafts of this piece, which made me substantively rethink the argument and pay more attention to the mechanics of writing.

2 "Programme of the Union of Russian People, 1905," in Rossiiskiia partii, soiuzy i ligi, ed. V. Ivanovich (St. Petersburg, 1906), 117-22, accessed March 11, 2020, https://com munity.dur.ac.uk/a.k.harrington/Russhist.HTML/.

3 The literature here is vast: several studies that have informed the present analysis are Laura Engelstein, Moscow, 1905. Working-Class Organization and Political Conflict (Stanford, CA: Stanford University Press, 1982); Victoria E. Bonnell, Roots of Rebellion: Workers" Politics and Organizations in St. Petersburg and Moscow, 1900-1914 (Berkeley, CA: University of California Press, 1983); Heather Hogan, Strikes, Wars, and Revolutions (Cambridge: Cambridge University Press, 1989); Charters Wynn, Workers, Strikes and Pogroms. The Donbass-Dnepr Bend in Late Imperial Russia, 1870-1905 (Princeton, NJ: Princeton University Press, 1992).

4 Peter Holquist, "Violent Russia, Deadly Marxism? Russia in the Epoch of Violence, 1905-21," Kritika. Explorations in Russian and Eurasian History 4, no. 3 (2003): $627-52$.

5 For instance, Bonnell, Roots of Rebellion, Ch. 8; Engelstein, Moscow, 1905, Ch. 4.

6 On the Russian right, see in English-language scholarship, Hans Rogger, Jewish Policies and Right-Wing Politics in Late imperial Russia (Berkeley, CA: University of California Press, 1986); Don C. Rawson, Russian Rightists and the Revolution of 1905 (Cambridge: Cambridge University Press, 1995), and George Gilbert, The Radical Right in Late Imperial Russia: Dreams of a True Fatherland? (London: Routledge, 2016). The existence of a large amount of Russian-language material on the theme should also be noted: monographs that have deeply informed the current analysis are Iu. I. Kir'ianov, Pravye partii v Rossii, 1911-1917 (Moscow: Rosspen, 2001); I. V. Omel'ianchuk, Chernosotennoe dvizhenie v Rossiiskoi imperii, 1901-1914 (Kiev: MAUP, 2007); S. A. Stepanov, Chernia sotnia. Chto oni sdelali dlia velichiia Rossii (Moscow: Iuza-press, 2013). I would also like to mention the excellent study by Zbyněk Vydra, Život za Cara? Krajni pravice v predrevolučním Rusku (Prague: Pavel Mervart, 2010).

7 On this point of right-wingers imagining catastrophe, see Mikhail N. Luk'ianov, "V ozhidanii katastrofy: eskhatologicheskie motivy v russkom konservatizme nakanune pervoi mirovoi voiny," Russian History 4, no. 31 (2004): 419-46.

8 Rogger, Jewish Policies, 188-89.

9 Haupt's remarks in "Tagungsbericht: Armed Associations and Political Violence in Belle Époque Europe, 12.12.2017-13.12.2017 Padova, in: H-Soz-Kult, 03.02.2018,” accessed November 7, 2019, www.hsozkult.de/conferencereport/id/tagungsberichte-7532; in this reading Haupt is clearly inspired by Max Weber. See for example Economy and Society. An Outline of Interpretive Sociology, ed. Guenther Roth and Claus Wittich (Berkeley, CA and London: University of California Press, 1968), 31-33.

10 On local organisation see for example Rawson, Russian Rightists, chs. 7, 8.

11 Iu. I. Kir'ianov, Russkoe sobranie: 1900-1917 (Moscow: Rosspen, 2003).

12 Iu. I. Kir'ianov, "Predystoriia pravomonarkhicheskikh partii v Rossii, 1902-1905 gg.," Istoricheskii arkhiv, no. 5 (2001): 112, 125, 126, 133-35.

13 Ibid., 134-35.

14 Klavdii N. Paskhalov, Russkii vopros (Moscow: Institut Russkoi tsivilazatsii, 2009), 106.

15 N. N. Novo-Aksaiskii, Politicheskaia evoliutsiia zapadnorusskoi chernoi sotni (18651914 gg.) (Minsk: V. P. Il'in, 2016), 181.

16 Figures cited in I. V. Ome'lianchuk, "Rabochii vopros v ideologii i praktike Rossiiskikh konservatorov nachala XX veka," Voprosy istorii 3 (2010): 22-37 (28). 
17 Soiuz russkogo naroda. Po materialam chrezvychainoi sledstvennoi komissii vremennogo pravitel'stva 1917 g., ed. A. Chernovskii (Moscow and Leningrad: Gosudarstvennoe izdatel'stvo, 1929), 62.

18 Figures cited in Iu. I. Kir'ianov, "Pravye i konstitutsionnye monarkhisty v Rossii v 1907-1908 gg.," Voprosy istorii, no. 8 (1997): 92-117 (100).

19 Figures cited in ibid., 92-117 (117).

20 Figures cited in Omelianchuk, "Rabochii vopros," 22-37 (26).

21 S. A. Stepanov, "Rabochie i chernosotennye organizatsii, 1905-1917 gg.," in Rabochie $i$ intelligentsiia Rossii v epokhu reform $i$ revoliutsii, 1861-fevral" 1917 g., ed. S. I. Potolov et al. (St. Petersburg: BLITS, 1997), 367-78 (372-73).

22 GARF, F. 102.OO, op. 316 (1905 g.), d. 999, Ch. 39, 1. A, 11. 286-286 ob: police report, Odessa, 2 July 1907. This source refers to the arrest of multiple unionists (soiuzniki), by which is meant members of the URP.

23 “Deiatel'nost' Khar'kovskogo Soiuza Russkogo naroda," Mirnyi trud, 3, 1907, 197.

24 Ibid.

25 S. E. Kryzhanovskii, Vospominaniia (Berlin: Petropolis, u.d.), 104; P. E. Shchegolev, ed., Padenie tsarskogo rezhima, Vol. 5 (Leningrad: Gosudarstvennoe izdatel'stvo, 1924-1927), 412-13.

26 Neil Weissman, "Regular Police in Tsarist Russia, 1900-1914," Russian Review 44, no. 1 (1985): 45-68.

27 Regional examples are in Soiuz russkogo naroda, 136, 239, 275, 281, 339.

28 Moskovskie vedomosti, 15 October 1905, 274, 1-2.

29 GARF, F. 102.OO, op. 316 (1905 g.), d. 999, ch. 39, t.1, 11. 49-50 ob.: circular from the council of the Tsarist Society of the Russian People, Kazan, 27 December 1905.

30 A report in the liberal Constitutional Democrat (Kadet) publication Vestnik narodnoi svobody (Messenger of the People's Freedom) described the common desire to oppose strikes breaking Russian industry. Vestnik narodnoi svobody, 24 May 1907, 20, cols. 1223-38.

31 Moskovskie vedomosti, 14 October 1905, 273, 1.

32 Vestnik narodnoi svobody, 24 May 1907, 20, col. 1232. This was the journal of the Constitutional Democrat (Kadet) party.

33 GARF, F. 102.OO, op. 316 (1905 g.), d. 999, ch. 39, t.1, 1l. 55-55 ob.: petition from the council of the Tsarist Society of the Russian People in Kazan to the Minister of Internal Affairs, 4 February 1906.

34 “Ocherk deiatelnosti Soiuza Russkikh rabochikh v gorode Ekaterinoslave," Priamoi put, February 1911, 47-50.

35 Ibid., 47-50.

36 Chernovskii, Soiuz russkogo naroda, 62; Stepanov, Chernaia sotnia, 394.

37 Chernovskii, Soiuz russkogo naroda, 62.

38 Mirnyi trud, 4, 1905, 190-91.

39 GARF, F. 102, op. 265, d. 565, 11. 995-96: letter from Count A. I. Konovnitsyn (St. Petersburg) to I. V. Sosnovskom (Odessa), 2 April 1912.

40 Moskovskie vedomosti, 8 February 1906, 37, 1.

41 I. Sobolev, Zabastovki (Moscow: I. M. Mashistov, 1906), p. 18. This publishing house was linked to the journal Mirnyi trud, cited earlier.

42 Ibid., 12.

43 Chernovskii, Soiuz russkogo naroda, 62.

44 Engelstein, Moscow, 1905, 210-11.

45 Chernovskii, Soiuz russkogo naroda, 145.

46 Cited in Stepanov, Chernaia sotnia, 347.

47 Stepanov, "Rabochie i chernosotennye organizatsii," 367-78 (372-73).

48 "Perepiska i drugie dokumenty pravykh 1911 goda," Voprosy istorii, ed. Iu. I. Kir'ianov, no. 11-12 (1998): 119-44 (121).

49 Odessa was one of a number of areas within the Pale of Settlement with a tradition of well-organised Jewish self-defence, which had been seen from 1903-6. The 
long-standing presence of Jewish self-defence groups in Odessa is mentioned briefly in Gerald D. Surh, "Jewish Self-Defence, Revolution and Pogrom Violence in 1905," in The Russian Revolution of 1905 in Transcultural Perspective: Identities, Peripheries and the Flow of Ideas, ed. Felicitas Fischer von Weikersthal et al. (Bloomington, IN: Slavica Publishers, 2013), 55-74 (60); Shlomo Lambroza, "Jewish Self-Defence during the Russian Pogroms of 1903-1906," Jewish Journal of Sociology 23 (1981): $123-34$ (132).

50 GARF, F. $102.0 O$, op. 316 (1905 g.), d. 999, ch. 39, 1. A, 1.92 ob.

51 GARF, F. 102.OO, op. 316 (1905 g.), d. 999, ch. 39, t.1, 1. 343: Rus', 12 December 1906.

52 GARF, F. 102, op. 265, d. 565, 1. 995: letter from Count A. Konovnitsyn (St. Petersburg) [URP] to I. V. Sosnovskom (Odessa), 2 April 1912; this source is reproduced in Iu. I. Kir'ianov, "Perepiska i drugie dokumenty pravykh (1911-1913)," Voprosy istorii, no. 10 (1999): 94-118 (114).

53 GARF, F. 102.OO, op. 316 (1905 g.), d. 999, ch. 39, 1. A, t. 1, 1. 82: Novoe vremia, 28 November 1906.

54 GARF, F. 102.OO, op. 316 (1905 g.), d. 999, ch. 39, 1. A, 11.92 ob., 98-99 ob.: letter from the director of the Russian Society of Shipping and Trade to the Mayor of Odessa, 20 April 1907.

55 GARF, F. 102.OO, op. 316 (1905 g.), d. 999, ch. 39, 1. A, 1. 300: Tovarishch, 9 August 1907.

56 GARF, F. 102.OO, op. 316 (1905 g.), d. 999, ch. 39, 1. A, 1. 286: police report, Odessa, 2 July 1907.

57 Kir'ianov, "Perepiska," no. 10 (1999): 94-118 (115).

58 Jacob Langer, "Corruption and the Counterrevolution: The Rise and Fall of the Black Hundred" (PhD diss., Duke University, 2007).

59 Odesskii pechatnik, 20 December 1911, 8, 10-11, "Delo redaktorov 'Od. Pochty' i 'Od. Slova'". I am grateful to Felix Cowan at the University of Urbana-Chicago for not only alerting me to this source, but for supplying me with his copy of the transliteration, which I have drawn upon here.

60 Kir'ianov, "Perepiska," no. 11-12 (1998): 119-44 (126).

61 Chernovskii, Soiuz russkogo naroda, 380.

62 GARF, F. 102.OO, op. 316 (1905 g.), d. 999, ch. 39, t.1, 1. 198: Birzhevye vedomosti, 7 October 1906.

63 GARF, F. 102.OO, op. 316 (1905 g.), d. 999, ch. 39, t.1, 1. 176.

64 GARF, F. 102.OO, op. 316 (1905 g.), d. 999, ch. 39, t.1, 11. 224-224 ob.: police report, Iaroslavl. 17 October 1906.

65 GARF, F. 102.OO, op. 316 (1905 g.), d. 999, ch. 39, t.1, 1. 286: Novaia Gazeta, 17 November 1906.

66 "Tagungsbericht: Armed Associations and Political Violence."

67 Gerald Surh, "The Role of Civil and Military Commanders During the 1905 Pogroms in Odessa and Kiev," Jewish Social Studies: History, Culture, Society 15, no. 3 (2009): 39-55.

68 Stepanov, Chernaia sotnia, 377.

69 Jeremiah Schneiderman, Sergei Zubatov and Revolutionary Marxism: The Struggle for the Working Class in Tsarist Russia (Ithaca, NY and London: Cornell University Press, 1978). I am grateful to Dr. Alexandra Medzibrodszky for alerting me to this important point. 